of waste materials such as groundnut shells, work on the formulation of insecticides for the malaria control campaign of the World Health Organization, the study of the flavouring constituents of pineapple using gas chromatography, and the analysis of the amino-acid content of animal feeding stuffs.
The open days gave many people an opportunity to see something of the wide range of scientific work which the Tropical Products Institute is doing on the renewable resources of the less-developed countries of the world. for producers and users alike.

B. R. SмITH

\title{
NEW INSTRUMENT ASSEMBLY WING OF THE CAMBRIDGE INSTRUMENT CO., LTD.
}

\begin{abstract}
A NUMBER of scientists, industrialists, and wellknown scientific and engineering journalists were among the 150 guests who attended a luncheon on October 23 to mark the opening of a new wing at the Cambridge Works of the Cambridge Instrument Co., Ltd. The guests were met by Dr. P. Dunsheath, chairman of the company's Board of Directors, and Mr. H. C. Pritchard, managing director, and the opening ceremony was performed by Sir Keith Joseph, M.P., Minister of State, Board of Trade.

After luncheon they toured the new wing, the Research Block which has been in use for two years, and Production Departments producing instruments for use in medicine and gas analysers for research and industry. In addition, a number of research projects and special displays of instruments made by the Company's two London factories were exhibited.

The new wing--which is $150 \mathrm{ft}$. long, $50 \mathrm{ft}$. wide and provides, on two floors, a working area of approximately 15,000 sq. ft.-is primarily intended to accommodate production departments for the final testing and assembling of instruments prior to dispatch. Immediately obvious features are the clean functional sweep of its two raised storeys, the groundfloor-level car-park and loading bay beneath, and the harmonious way it blends with the research laboratories, opened two years ago (see Nature, 184, 1364; 1959), to which it has been planned as a logical
\end{abstract}

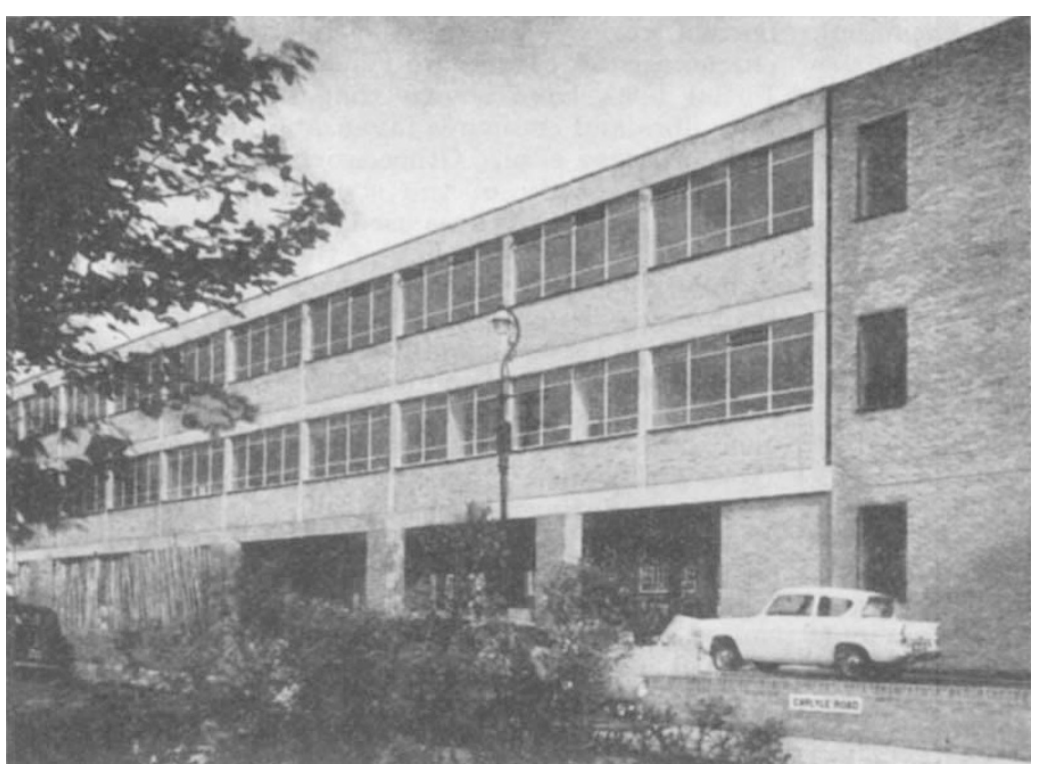

Fig. 1. Instrument assembiy wing of the Cambridge Instrument Co., Ltd.

architectural extension, and to which one end is joined by connecting doors. The other end of the wing is connected to other works buildings and the loading bay by a link block containing stairs and toilet facilities.

Structurally, the reinforced concrete frame of the raised building rests on a solid concrete slab supported by two rows of circular columns along its length, over which the slab is cantilevered out about $8 \mathrm{ft}$. front and back. The second floor and roof are mounted on pre-cast pre-stressed concrete beams spanning the full width of the building, so that the floor areas of both storeys are uninterrupted by intermediate columns. Windows are double glazed and the infill panels below faced with golden buff bricks. Air supplied throughout the building is conditioned and filtered by plant contained in two penthouses on the roof. Essential services, ventilating and heating inlets, gas, compressed air, water, electrical supplies, telephones, etc., are laid in horizontal ducts running the full length of the building below the windows and, to reduce fire risks, all work benches are wired with mineral-insulated metal-sheathed conductors.

Two-thirds of the first-floor area, adjacent to the entrance hall, is used as Production Offices and the remainder is occupied by the Microanalyser Depart. ment. This Department is responsible for assembling and testing 'Microscan' X-ray analysers and for the production of sealed and flow-type proportional counters. It is also concerned with the commissioning and servicing of 'Microscans' and operates an advisory service, including the analysis of samples provided by prospective customers. Complete installations are assembled in specially designed cubicles, each of which is supplied with its own special services. Conditioned air supplied to this Department undergoes an additional degree of filtration in view of the need for absolute cleanliness during final assembly of a 'Microscan'.

The whole of the second floor is devoted to final assembling, wiring and testing of a wide range of galvanometric indicators, recorders and controllers. Here again a dustfree atmosphere, so necessary for the assembly of intricate precision instruments and components, is provided. The functional interior design with its modern décor makes the new building a pleasant and comfortable place in which to work.

The new wing is the latest illustration of the considerable 
development of the Company in recent years and has been made necessary by the increasing num. bers of new and improved instruments developed by the Research Department. The building, which was designed by Edward D. Mills and Partners, architects, was completed in less than a year by the contractors, J. Jarvis and Sons, Ltd.

J. G. HAMMOND

\section{LIFE AND ITS ENVIRONMENT IN ANCIENT SEAS}

$\mathrm{D}$ URING the British Association meeting at Norwich, the Geology and Zoology Sections (C and D) held a joint session on "Life and its Environment in Ancient Seas".

Prof. C. M. Yonge, president of Section D, was in the chair and about 150 persons attended. The programme was designed as a general session covering a wide range of palæoecological topics, but unfortunately the opening address by Prof. Kaare Strøm (professor of limnology, University of Oslo), entitled, "In Quest of Ancient Seas", and the paper by Dr. R. H. Cummings (Department of Geology, University of Glasgow) on the "Polæoecology of Foraminifera in Reef Limestones" were both cancelled, and so the scope of the meeting was more restricted than originally planned.

The paper by Dr. K. A. Joysey (Department of Zoology, University of Cambridge) on "The Life of Cephalopods in Ancient Seas" was a discussion of existing views on the mode of life of fossil forms, considered in the light of new information about living cephalopods. Dr. Anna Bidder (Department of Zoology, Cambridge) showed a series of excellent colour slides of the living Nautilus and gave an account of her observations, largely based on freshly captured specimens living in the aquarium at Noumea, New Caledonia. The paper by Mr. R. W. Sheldon and Dr. F. M. Broadhurst (Department of Geology, University of Manchester) and Dr. J. G. Potts (United Steel Companies, Ltd.) on "Aspects of the Palæoecology of Marine Faunas in the Upper Carboniferous of the Southern Pennines", was a preliminary account of work still in progress seeking to elucidate the relationship between certain fossil faunas (mostly goniatites, lamellibranchs and brachiopods) and the petrology of the enclosing sediment. Hence, the session as a whole had an emphasis on molluses, particularly cephalopods. Although unplanned, this bias came as a natural sequel to the molluscan theme of Prof. Yonge's presidential address.

Many 'palæoecological' publications (including some by the present author), are merely records of association and distribution, and offer little interpretation of the relationship between the fauna and the environment. The appreciation of $a$ fossil biological system demands not only the reconstruction of the animals themselves but also of how they lived, what they did, their effects on other animals and on the environment. The Norwich session served well to illustrate this palæobiological approach to palæoecology.

In surveying the problems of buoyancy control, Dr. Joysey noted that the majority of living cephalopods are more dense than sea-water and support themselves by swimming, but Sepia, Spirula and Nautilus have a density near that of sea-water, owing to gas enclosed in rigid-walled chambers. Unlike the swim-bladder of a fish, the volume of the cephalopod float is not affected by changes in pressure. Hence, so long as some mechanism prevents the hydrostatic pressure from forcing liquid into the chambers through the porous siphuncular tube, changes in depth should not affect the buoyancy. Denton and Gilpin-Brown have recently shown that Sepia can adjust its buoyancy by pumping liquid in and out of the chambers, like a submarine altering ballast. This liquid has a lower salt concentration than the body fluids, and so osmotic pressure helps to counteract hydrostatic pressure. Dr. Joysey observed that as Spirula and possibly Nautilus are recorded from depths below that at which an osmotic mechanism would fail, some other mechanism must be sought if the gas is to be maintained in the chambers. An increase in the gas pressure would prevent liquid from flowing into the chambers and also prevent implosion of the shell, but any other mechanism whereby the siphuncular tube might become temporarily impermeable to liquid must be accompanied by a shell sufficiently strong to withstand the external pressure.

Dr. Bidder showed some photographs of Nautilus in a state of nearly neutral buoyaney swimming in mid-water or resting on the bottom, and others of it floating with part of the shell breaking the surface of the water. She had also observed under-buoyant animals hanging by their tentacles, and had found that individual specimens could adjust their buoyancy.

Dr. Bidder stated that the gas in the chambers was not under pressure in a specimen just hauled from a depth of nearly 200 metres. She had also extracted quantities of liquid from the gas chambers of Nautilus and using X-ray photographs she demonstrated that when a specimen had been turned upside down the shadows which were presumed to be bodies of liquid had indeed run to the opposite side of the chambers. She found no evidence of living tissue in the gas chambers of Nautilus.

In reviewing present-day interpretations of the posture of various fossil cephalopods, Dr. Joysey noted that the position of the gas chambers in orthoconic shells at first sight suggested that they hovered vertically in the water, or rested on the sea-floor like church steeples. Alternatively, if a load were present at the apical end, such as liquid in the apical chambers, they could have adopted a horizontal posture. It is generally accepted that, in some forms, this apical counterbalance was provided by solid deposits within the siphuncular tube. Other forms have deposits within the apical gas chambers, but there has been some controversy as to whether these were laid down by a cameral mantle or whether they are postmortem mineral infillings. In view of the recent findings on living forms, Dr. Joysey suggested that serious consideration should be given to the possibility that these deposits might have been precipitated during life from solutions transported through the walls of the siphuncular tube.

By analogy with orthoconic nautiloids, Dr. Joysey pointed out that one of the functions of the belemnite 